

\section{The report an morice}

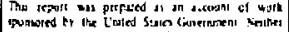

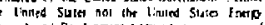

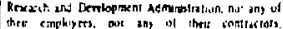

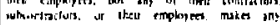

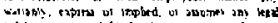

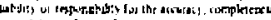

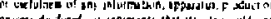

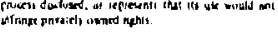

Trapped Particles and Harmonic Generation

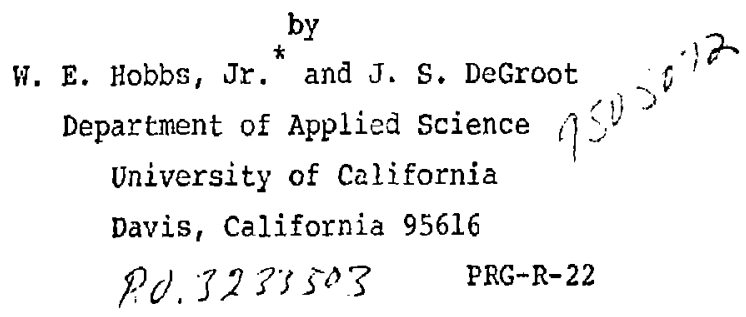

\section{MASTEFT}

MAS

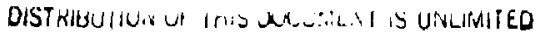




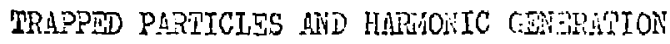

ii. I. Koobos, Jr. and J. S. DeGroot

Department oi Applied science,

University of California, Davis, California 95616

\section{Mbstract}

A no:pl Iluir-particle alsorithm has been used to study the evolution of continuously sencrated ion acoustic waves numerically. The code permits the simultaneous analysis of the two nonlinearities inm volved; weve sieepening or harnoric generation, a iluid eifect; and wave daroing and anplitude oscillations, a perticle efiect. For a tenperature ratio $10<\mathrm{T}_{\mathrm{e}} / \mathrm{T}_{\mathrm{i}}<30$, the behavior of low amglitucie lons navelength $\because$ aves is well described by a Kortewegcevries equation augnented to include a time depencent darnjing torm. 


\section{INTPODUCTIOS}

During the last docsde, there has beon cxionsive exonination of nonlinecrities in the ion acoustic system. For a uniford field-free plasma of vark electrons and cold ione a fluid model may be applied. In the wedly nonlinear lirit the fluid equations reduce to the kowionseveries esuation. ' In the laboratory frare this equation is wition

$$
\frac{\partial \phi}{\partial t}+\frac{\partial \phi}{\partial x}+\phi \frac{\partial \phi}{\partial x}+\frac{1}{2} \frac{\partial^{3} \phi}{\partial x^{3}}=0 .
$$

The independent variables $x$ and $t$, displ cenent ond time, are scaled to the electron Dobye len frectroy $\omega_{\text {pi }}^{-1}$ respectively. The state variable $\phi$, tho potentia?, is sasad to $\mathrm{T} / \mathrm{e}$, the elcotron tamperture in volts.

Endtion (1) is nonlinger through the convective tem o (oe/ox) which 1 sas to the eneration of harmonic contont or wave staponing. Fisis is linited by the dispersive term $\partial 3_{\phi} / \partial x$. In ar inini:e systex the belance of these terms results in a civen iisturbancs evolving into a series of pulses whicin are separated by arbitrarily lerse distances. These pulses are called solitery vaves or solitons, The periodic system also exhibits similex pulses with an adritional quality. once the system attains its maximurn harmonic content, it will appoar to reverse in time, to "cie-steepen", and to reoroduce the initial condition."

Ion acourtic waves also exhibit nonlinear arolitude oscillations aue to resorat garticles. The analysis of this effect ${ }^{3}$ was oricinally nade ror electron plasna weves, but sato et al. 4 
have exporimentally verified that it alco applics to finite amolitude ion acoustic waves. For larger anolitude vaves, the trapped particles are more appropriately called reilected particles.

Ion reflection from a stoepenine wave iront porforms an inportant role in various plasma hoating schemes. 5

For high temperature ratios $\left(T_{e} / T_{i} \geq 30\right)$ the effect of the trapped particles becones negligible. Ijinevise, for short wervelengths (as $k \rightarrow \lambda_{D e}^{-1}$ and $\omega \rightarrow \omega_{p i}$ ) the effecis of harmonic generation may be ignored. In Eengral, however, these two nonlinearities act tocether to govern the evolution of the ion acoustic systen.

In this ariicle we report on our numarical studies of continususly generated ion acoustic waves where boch fluid and kinetio yoninearitios are considured. Our analysis was iade posstble

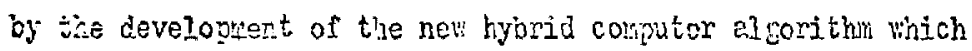
ve :ill cescribe in the next section. We will then doscribe our resiiss throuch a rodel problem. Ve vill consider a situation which is well describod by two Fourier modes. Finally, our results will be intorproted in terres of a matrematical model,

\section{THE FLUID-PARIICLE ALCORTTMA}

Several hybria codes have boen written which treat one species as a fluid and the other as an ensemble of particles. For example, Mason ${ }^{6}$ used a code with perticle ions and isothermal fluid electrons to stuay binetic efiects in the ion acoustic system. In this section we describe an al gorithm wich aifiers: markedzy from previous codes. It represents a single species 
as a composite of iluid ara traticles.

The basic proputics of ion acoutic waves no nell described by a one dimensional, to-fluid rodel. No a basis for our algorithn we betin with this wotel. It is sumprized by the flutd cquations for the ions,

$$
\frac{\partial}{\partial t}\left[\begin{array}{l}
n \\
v
\end{array}\right]+\frac{\partial}{\partial x}\left[\begin{array}{c}
n v \\
v^{2} / 2+\phi+3\left(\frac{T_{i}}{T_{e}}\right) \ln n
\end{array}\right]=0,
$$

and Poisson's equation with lexieli-Boltaman electrons,

$$
\frac{\partial^{2} \phi}{\partial x^{2}}=\exp (\phi)-n \text {. }
$$

In tise ecuations $n$ is the density scaled to the equilibriut den Sit: $n_{0}, v$ is the reiocity sceled to the ion ccoustio velocity es, arc $\vec{i}_{i}$ and $\mathrm{T}_{0}$ are tho ion cna electron tenporatures, respectively. Bec-uso ion inetic sfocts are neglocted, these fluid equations ane not va?in unjoss tha ion-electron terperature ratio is sme2I. Yonever, as Jone as ions are resonant with the wave only in the tail of the ion astribution, we can Givice up the ion distribution into nonrosonent (thernal) and resonont (suprathernal) ions. Ne use fluic ecuations to follo:! the dynamics of the thermal ions, and the Vlasov oquation to follow the dynarics of the suprathormal ions. Rathor than oxplicitly solving t!le Vlasov eountion, we represent tie supratiernal particles as macroparticles. tais perticle portion is represented mathematically as follows,

$$
f(x, v)=\sum_{p} S_{p}\left(x-x_{p}\right) \delta\left(y-v_{p}\right)
$$


Here, $\delta$ is the Dirac delta function and $s_{6}$ is a rocturular impulso function, the cloud representation of a macroperticlc; $x_{p}$ and $v_{p}$ are the position anc velocity of a particle, wich cvolve accordins to Lag-angian eouations of motion,

$$
\frac{d x_{p}}{d t}=v_{p}, \quad \frac{d v_{p}}{d t}=-\frac{\partial \phi\left(x_{p}\right)}{\partial x}
$$

The usual cloud-in-cell alcorithm may be used to calculate the dyramics of the particles.

The tro peris of the distribution combine to give the ion charge in a hybrid Poisson's equation,

$$
\frac{\partial^{2} \phi}{\partial x^{2}}=\exp (\phi)-p_{f} n-p_{p} \int_{-\infty}^{\infty} f d v
$$

Ie: $\equiv, D_{\hat{I}}$ and $p_{p} \equiv$ exe the reights of the fluid and particle purtions ci tre distribution, respoctively $\left(p_{f}+p_{p}=1\right)$.

A typical initial ion distribution is copjeted in Fis. 1. The Gejssian distribution is dissectod horizontally inte fluid cnd Darticle components. The thermel part is cominated by the fluid portion. The upper bound in vilocity for this fluid cor nent is $v_{h}$, which we call the hybrid velocity parsinger. It is usecl for determining the reights of the portions of the distribution and for enalyzing other properties of the alcorithm. 8

Since we close the fiuia enuations lsine en adioontic equation of siate, $v_{h}$ is closen to be proator than tinc therinal velocity, $v_{t}$. To incluce tha coningrit wave-particle effects, $v_{h}$ is choson 
to be loss than the lower bound of the resenence region of the vave, $v_{p h}-\left(\phi_{\text {max }}-\phi_{\text {tin }}\right)^{2}$, where $v_{p h}$ is tho phese velocity of the "eve. Together these constrints for"s s critorion for the application of our algorith,

$$
v_{t}<V_{h}<V_{p h}-\left(\phi_{\text {max }}-\phi_{\text {min }}\right)^{1 / 2}
$$

This critarion jes often seticnied by ion scodstic waves. The phate valosity of lone wavelungth ton coustic waves is near the ion cooustic velocity end the setio of this to the ion thermal velocity $v_{t i}$ is equal to the souare-root of tho electron-ion temperaturs ratio,

$$
c_{s} / V_{t i}=\left(T_{e} / T_{i}\right)^{1 / 2}
$$

We notr thet this juxtrosition of fluid and article mocols

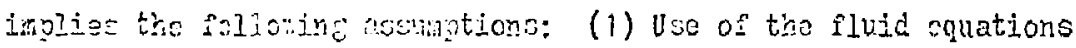
for the centrel portion of the distribution recuires that there be solit sechenise, such is collisions, to rontein the foria of the distribution thera; (2) Use of the particle representation in the resonance region revires thet the cistribution there be collisionless.

IIT. TES BEHNIOR OR SWLL HPLTUES IISTURERCES

A typical result for a mall-anolitude ion acoustic wave is surnorizos in Fie. 2. The initial conition described a monochrombic $4 ;$ density we wits a weleneth of $3 \pm \lambda_{\text {De }}$. The electron-jon tomporeture rot:o wes is and tho hyorjd volocity parateter 
wes $2.5 v_{t i}$. Throurcout the calculation the systom we acll described by the inst tro Fourior rodos. The thiod sole had a rayimun amituce o: $0.5 \%$

As in the orveil theory, ${ }^{3}$ tile trappol yerticles are observea to circulate ithin the sopuratix thereby infucheing the wave anplitude. The shape of tine segaratriz cvolvas slowy, since the wave is no loner monociroratic. Using the initial volucs of the

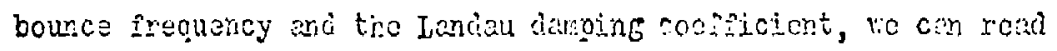
the monochromatic asplituie oscillations from a graph prosented by rorales and crieil. This is included as the dence lino in the fingre. We rote thet near the points ware tho second modo

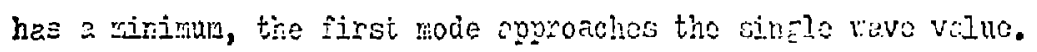
These tzos at yich the syston revurne to baing narjy monochrom-ito Ene celies necurancos. The wave doos not roturn to its

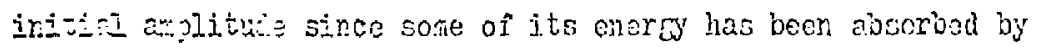

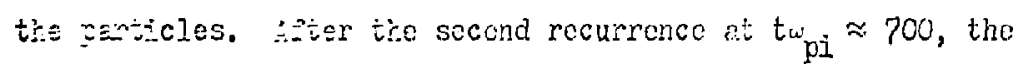
ions tav ylese-wese to forn a velocity platom in tho vicinily

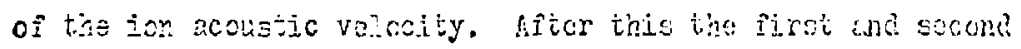

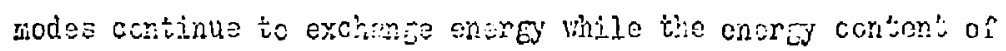
the periticles remains aporovinetely const:nt.

It was generally believed that nonlincurities constituled the first ston in the ingrosable incroace in eatropy. Fermi et

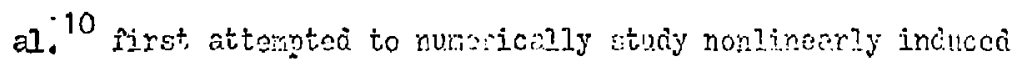
therualization. They found that their syetcme dice not thormalizo and observed tho recurroncos. In our cimuletions we soe that

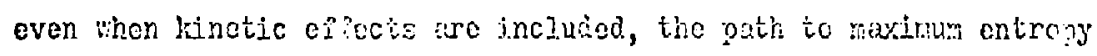
may still include a ray steition. 


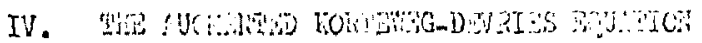

ic will no" roviow our tesuretions, "o have assunth tho

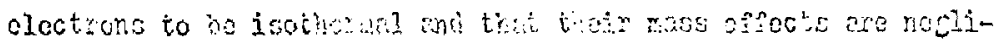

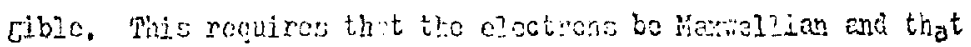

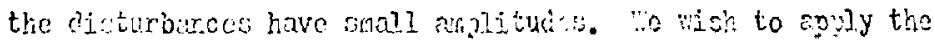

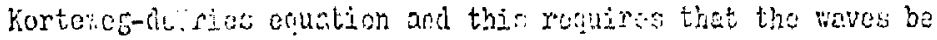

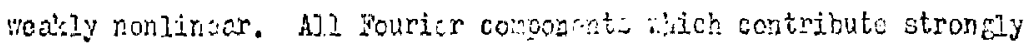
to the shape of the ruve must have wivelonging Ionger than $\sim 10 \lambda$ De" This exphaizes the requirenont for encil awplituds mes:

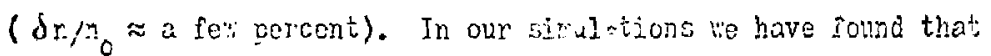
the son racurtic syrtow has a strone propensity to steepen.

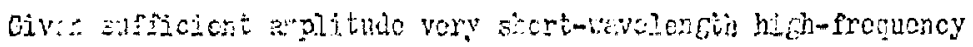
comanenis will so driven by the procens of hamonic generation.

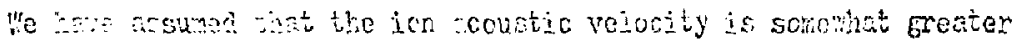

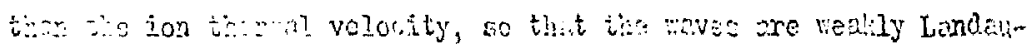

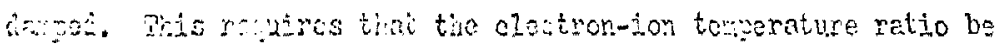

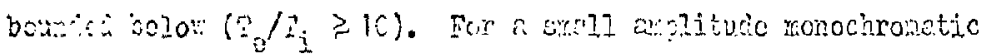

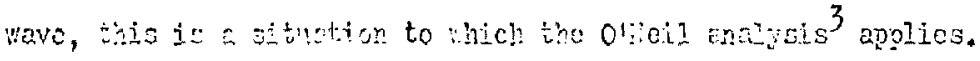
Tho andiction ba ha thoory rocuiras trat the daping incuce changos ritabaticelly in the potontix. This woss that the daryino only incuces a neglifible muber of paricles to bo trapod and dotrogos.

In addition to donging, in the ion soustic gyser. ve must

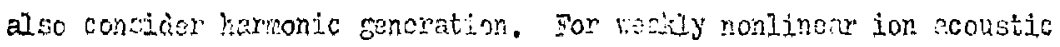
wvos, this it a very slor process ard tro potontial variations

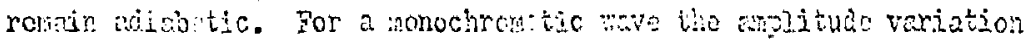




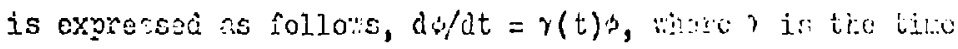
depercient dangirs coefficiont. ${ }^{3}$ To accuut for tho harmoric generation anc the disporsion in tho ion icouric syatem, we assure that do/at is expresaed as the leit-hend sicio of Ex. (1). This is our augentod hortekes-deiries equation,

$$
\frac{\partial \phi}{\partial t}+\frac{\partial \phi}{\partial x}+\phi \frac{\partial \phi}{\partial x}+\frac{1}{2} \frac{\partial^{3} \phi}{\partial x^{3}}=\gamma(t) \phi .
$$

Tappart and Judice ${ }^{11}$ have studied the recurrence phenomond associated iith this eçuation when thore are no resorarti particles; i.e. $\gamma \equiv 0$. They nots th then the syotem is :ell siscoidos by t:10 Fourior modes, tha recurmence time way

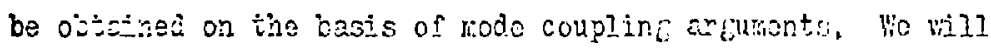

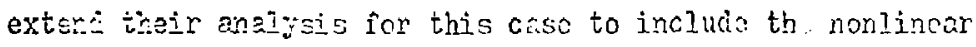
daxpine $i \leqslant r s$.

Fe notenticl is assured to be well described by a Fourion mode art its înst harmoric,

$$
\begin{aligned}
& \phi(x, t)=\rho_{1}(t) \exp \left\{i\left[k x-\omega_{1} t-\theta_{1}(t)\right]\right\} \\
& +\rho_{2}(t) \exp \left\{i\left[2 k x-\omega_{2} t-\theta_{2}(t)\right]\right\}+c \cdot c .
\end{aligned}
$$

Here $P_{1}$ ard $P_{2}$ are the arplitrdes of the tio llodes; $\omega_{1}$ and (1) are the frequencies witich correspond to the wave nuxbors $k$ and ?k respectively; and $O_{1}$ and $O_{2}$ aro tine-dcpendont phree an olos. For this equation to be justiried the mode anlitudics must satisfy the inequalities, $\rho_{2}<\rho_{1}<1$, or clse the third mode must be consilered. 


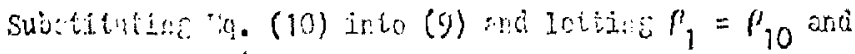

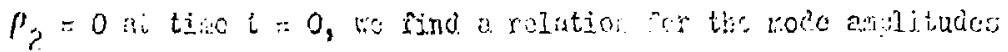

$$
p_{1}^{2}+p_{2}^{2}=\left(p_{10}^{2} / p^{7}\right)
$$

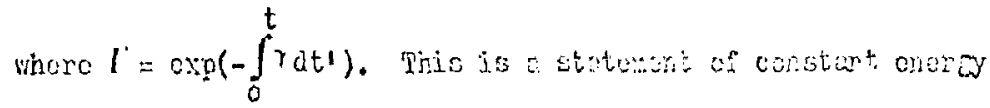
vhich ir confistont with our oborvations of the previous saction.

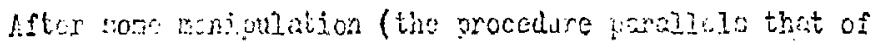

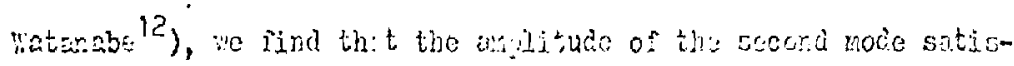

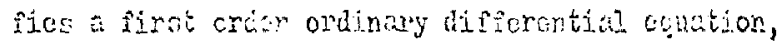

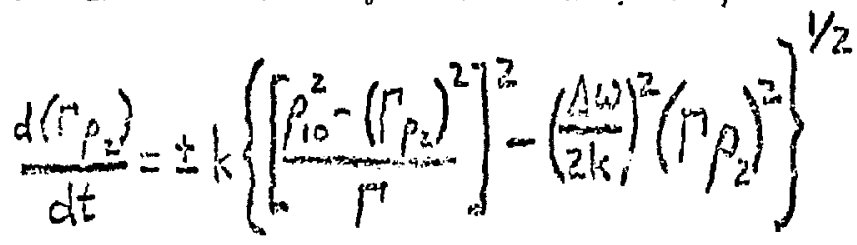

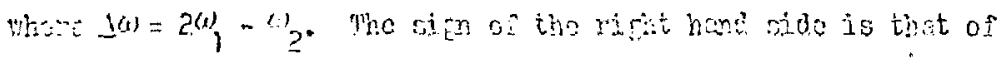

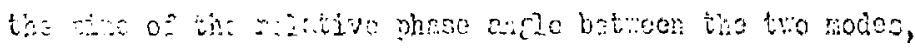

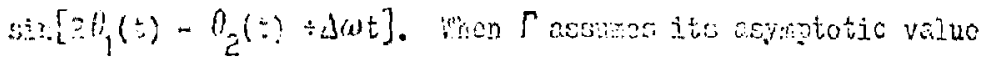

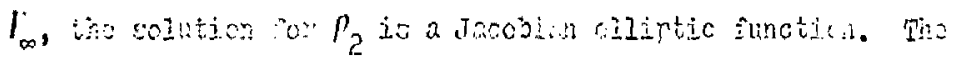

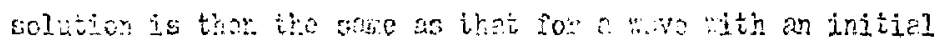

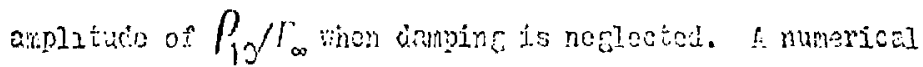
solution oî 30 . (11) and (12) is shown in Fig. 3 [ro havo used

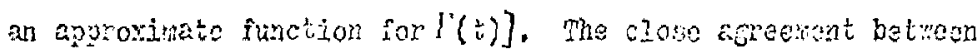
these reoults and the hybrid results (Po. 2) should be noted. The time interval siom in $7 \mathrm{ic} .3$ corresponds to tro $\approx 1050$,

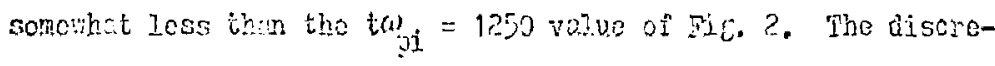

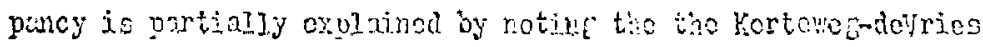
cquation which we inve user assures cold ions. Tanayt 13

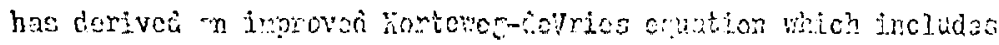


terprature fluid oñocis. Using it Topnert and Judice ${ }^{11}$ bsvo obtained formulo for the recurrence tire of ion acoustic waves. Substituting the paraneters of our rodel problem into their small-anplitude (two-mode) foritula, we find a rocurrence ooriod equal to $276 \omega_{\mathrm{pi}}^{-1}$ for cold ions and $302 \omega_{\text {pi }}^{-1}$ for jons wi.th $\mathrm{T}_{\mathrm{i}} / \mathrm{T}_{\mathrm{e}}=16$. This lengthening of the recurrence poriod brings the time intervals ô the two figures into more saticfectory correspondence. Further inproveyent is expected if r:e take into account the lons-wavelength exparsion used in the Korteveg-devries equation. 11

\section{STIVIVII}

Witt cur fluid-particle of gorithn we were ablo to sucessinly sticy recurrence ohenomena with kinetic effects. The recurrence o: $\vdots$ : Jutiso ${ }^{11}$ and has jeen experimontally observoa by Jhozi. 14 Ve consicizact a situation which corresponds approxiutatcly to Iheti's laboretwry conditions where tro Fourier nodes dominate the system. Ye observed the circulation of the trepoed ions within the separatrix and noted that the level of our fundanental vavos at the recurrences was apyrorimately equal to that of the o'feil solution.? Fhis led us to assume that an augmented Korteweg-revries equation could be used to model our system in restricted situations. The solution of this equation compared satisfactorily with our sinulation resilts.

He have performed numerical computations involving larger ampl itude waves of longer wavelonghitho. Our results are consistent witiz the theory of the provious section when the lattcr is 
applicable. Trapped garticles talse cnares inron tho wave, but the hemonic coneration continuss.

\section{ACWIOWLDDSTLNT}

One of the authors (my) aclenowledes heloful discussions with C. P. Defeef of the University of Californis, Davis, and assistanco with tho nanuscript from D. L. Booli of the liaval. r:esearch Laboratory.

This work wes supprted by the Iawronce Livermore Lavoratory under intrarural ordor 6224305 and in part by the National Resesrch Souncil. 
*NRC Resident Research Lssocinte at the Nevil Rosearch Jaborasory, Vashington, D.C. 20375.

1. I. "Ieshimi anci T. Taniuti, Phys. Rev. Lett. 17, 965 (1966).

2. M.J. Zabusky and M. M.Kruskal, Phys. Rov. Lott. 15, 24,0 (1965).

3. T. ONeil, Phys. Pluids , 2255 (1965).

4. I. Sato, H. Ikezi, Y. Yamahita and L. Tahahochi, Phys. Rev。 Let, 20, (1963).

5. R. Chodura, I:ucI. Eusion 15, 55 (1975).

6. ‥J. Kason, Phys. Pluids 13, 1042 (1970); Phys. Fluids 14, 1943 (1971); Phys. Fluids 15, 845 (1972); Phys. Fluids 15, 1032 (1972); Phys. Fluids 15, 1162 (1972); Phys. Fluids 15, $2072(197 ?)$.

7. C.R. Birdsei? and D. Tuss, J. Comput. Phys, 2, 494 (1969).

8. サ... Lobbs, Fh.D. thesis, University of Califormia, Davi. (1975); $\because .3$. Fobbs and J.S. DeGroot, to be published in J. Comput, Pnys.

9. G.J. Morales and T.Y. ONoil, Phys. Rev. Lott. 23, 417 (1972). 10. E. Fermi, J. Pasta and S. VIem, in Tnrico Fermi, Collacted Papors, University of Chicago Press, Chicago (1965), Vol. IT, p. 977.

11. T.D. Tappert and C.N. Judice, phys. Rev. Iett. 29, 1308 (1972).

12. S. Watanabe, J. Dlasma Dhys. 13, 217 (1975).

13. T.D. Tappert, Phys, Fluids 15, 2446 (1972).

14. H. Ihezi, Phys. Fluids 16, 1668 (1973). 
Fig. 1. The initial rluid-ponticle distribution. The upper bound of the fluid portion is $v_{h}$, the hybrid velocity paraneter.

Fic: 2. The evolution ô a smell erplitude ion acousicic ave. The initial condition is a monochromatic doity wave $\delta \mathrm{n} / \mathrm{n}_{0}=0.04 \sin \left(\pi \mathrm{r} / 15 \lambda_{\mathrm{De}}\right)$. The desned line is the olieil solution for a single Fourier mo:o.

FiE. 3. Solution of the augnented Foriover-devrios equation. The consiraints are the sane as those for Fig. 2. The dashed line is $P_{10} l$, the mock solution for a single Fourier modo.

\section{NOTICE}

"This report was prepared as an icsount of work sporsored by the United States Government. Neither the United States nor the United Stales Energy Research \& Development Administration, nor any of their employess, nor any of their contractors, subcontractors, or their employers, makes any warranty, express or implied, or assumes eny legal liability of responsibility for the accusscy completeness or usefulness of any information, uppdratus. product or process disclused, or represents that its use would not infringe privately-owned rights." 


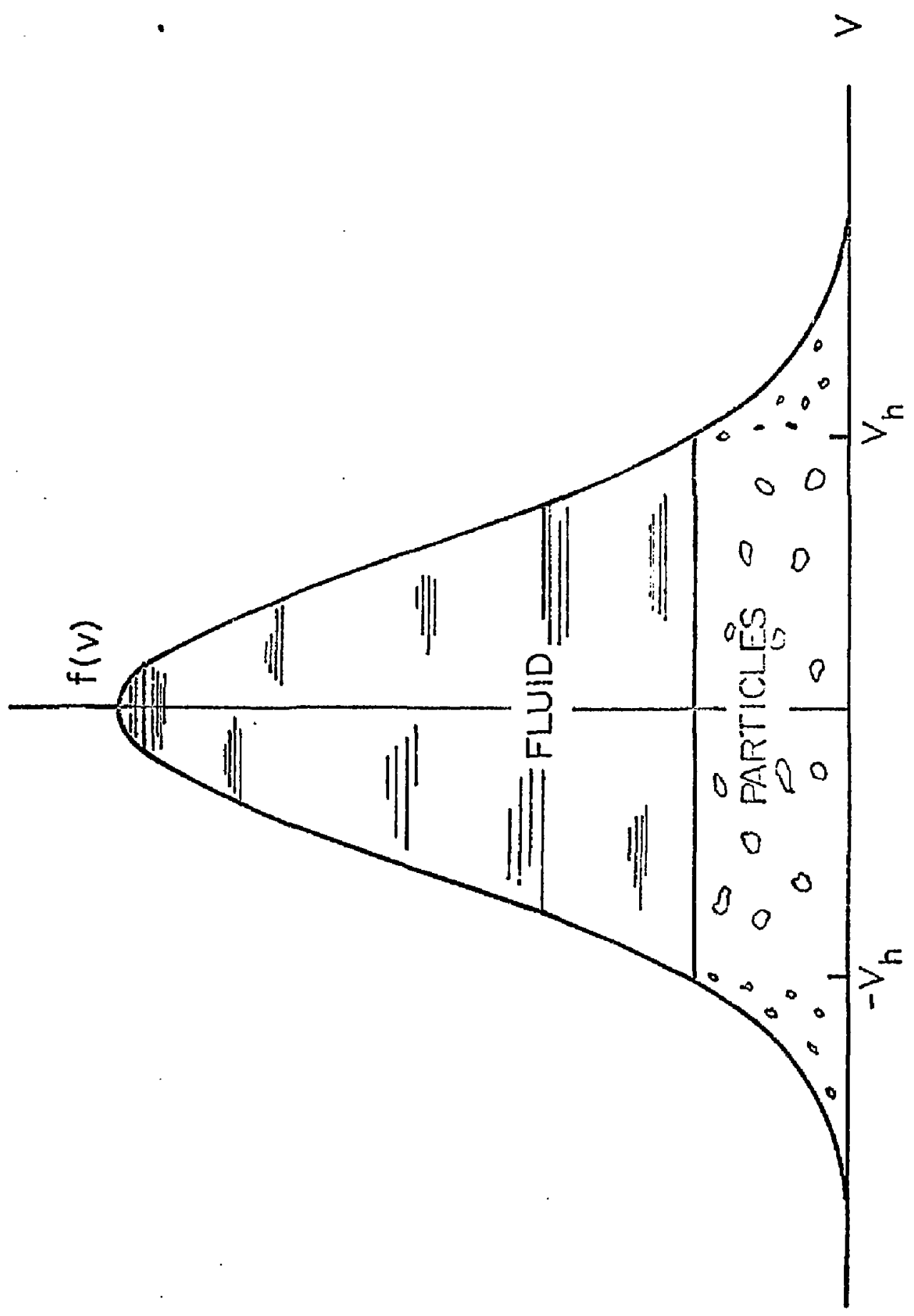

Fipe 1. 


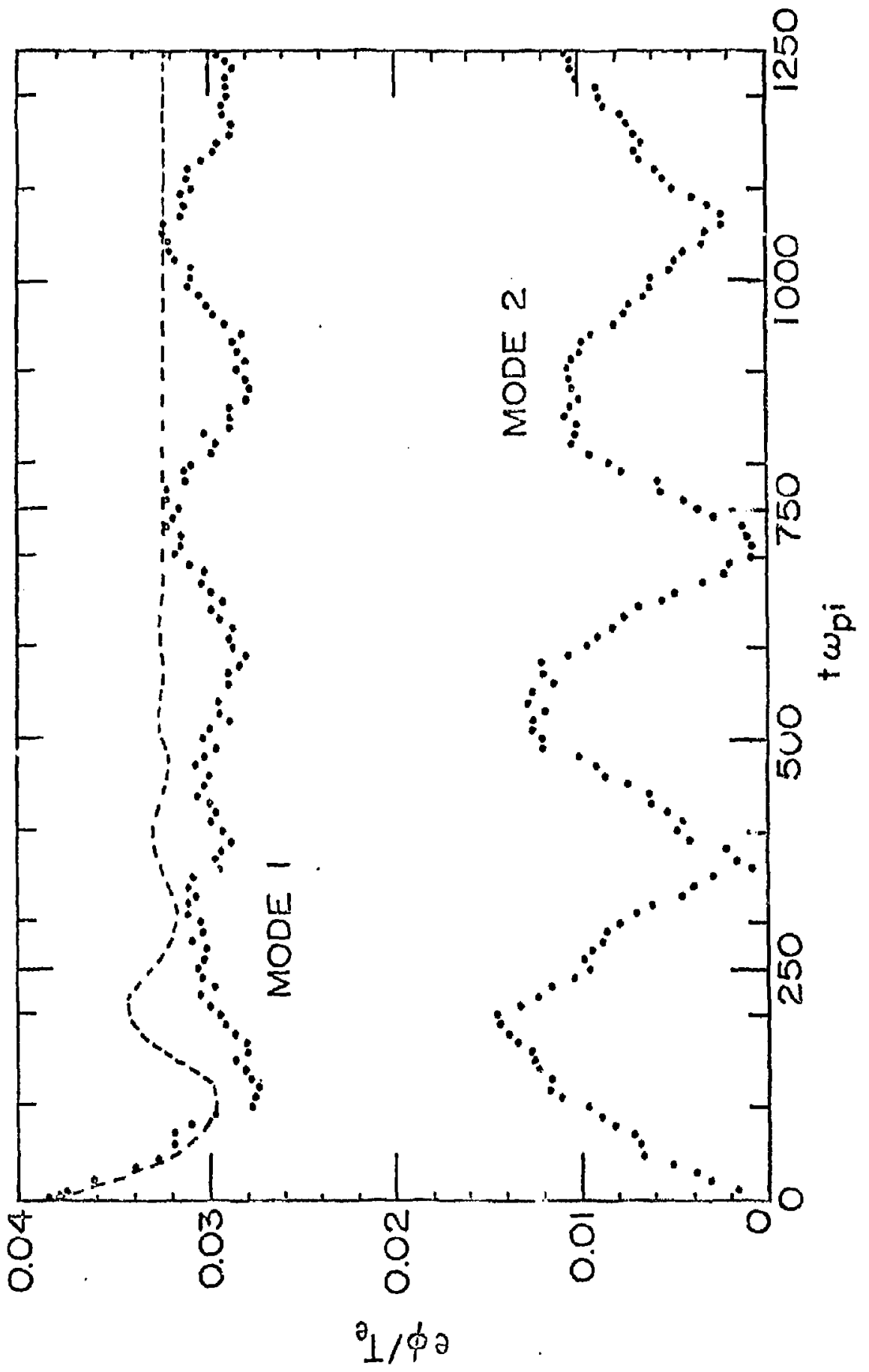

Figure 2 


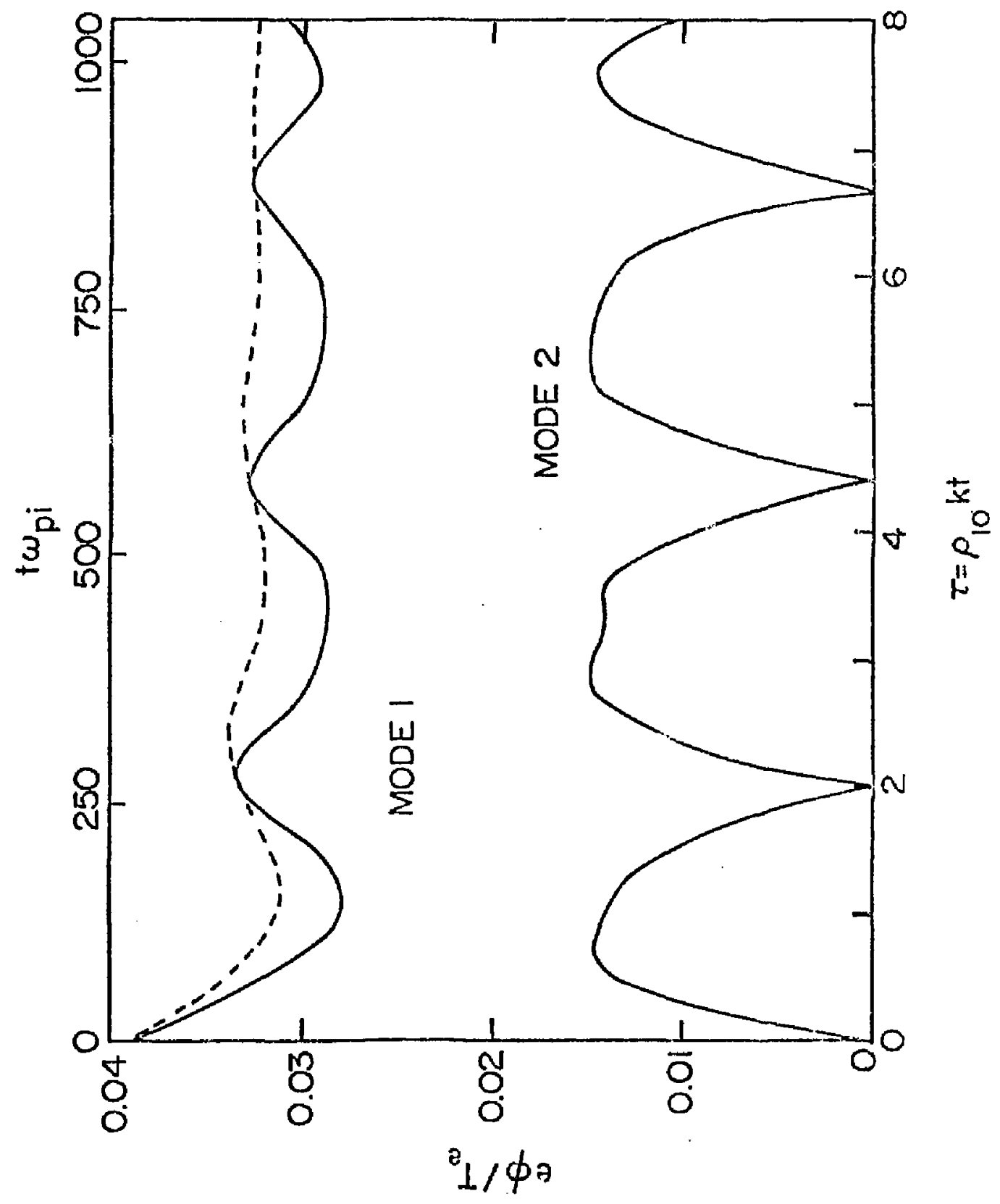

Figure 3 